\title{
In-Depth In Silico Search for Cuttlefish (Sepia officinalis) Antimicrobial Peptides Following Bacterial Challenge of Haemocytes
}

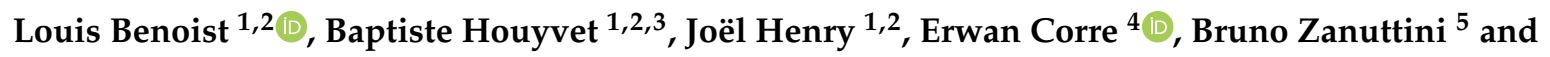 \\ Céline Zatylny-Gaudin $1,2, *$ (D) \\ 1 Normandy University, Unicaen, CNRS, BOREA, 14000 CAEN, France; louis.benoist@unicaen.fr (L.B.); \\ baptiste.satmar@orange.fr (B.H.); joel.henry@unicaen.fr (J.H.) \\ 2 Laboratoire de Biologie des Organismes et Ecosystèmes Aquatiques (BOREA) Université de \\ Caen-Normandie, MNHN, SU, UA, CNRS, IRD, Esplanade de la Paix, CEDEX, 14032 Caen, France \\ 3 SATMAR, Société ATlantique de MARiculture, Research and Development Department, \\ 50760 Gatteville, France \\ 4 Plateforme ABiMS, Station Biologique de Roscoff (CNRS-Sorbonne Université), 29688 Roscoff, France; \\ corre@sb-roscoff.fr \\ 5 Normandy University, Unicaen, Ensicaen, CNRS, GREYC, 14000 Caen, France; bruno.zanuttini@unicaen.fr \\ * Correspondence: celine.gaudin@unicaen.fr
}

Received: 23 July 2020; Accepted: 19 August 2020; Published: 24 August 2020

check for updates

\begin{abstract}
Cuttlefish (Sepia officinalis) haemocytes are potential sources of antimicrobial peptides (AMPs). To study the immune response to Vibrio splendidus and identify new AMPs, an original approach was developed based on a differential transcriptomic study and an in-depth in silico analysis using multiple tools. Two de novo transcriptomes were retrieved from cuttlefish haemocytes following challenge by $V$. splendidus or not. A first analysis of the annotated transcripts revealed the presence of Toll/NF- $\mathrm{BB}$ pathway members, including newly identified factors such as So-TLR-h, So-IKK-h and So-Rel/NF-kB-h. Out of the eight Toll/NF-kB pathway members, seven were found up-regulated following $V$. splendidus challenge. Besides, immune factors involved in the immune response were also identified and up-regulated. However, no AMP was identified based on annotation or conserved pattern searches. We therefore performed an in-depth in silico analysis of unannotated transcripts based on differential expression and sequence characteristics, using several tools available like PepTraq, a homemade software program. Finally, five AMP candidates were synthesized. Among them, NF19, AV19 and GK28 displayed antibacterial activity against Gram-negative bacteria. Each peptide had a different spectrum of activity, notably against Vibrio species. GK28 — the most active peptide-was not haemolytic, whereas NF19 and AV19 were haemolytic at concentrations between 50 and $100 \mu \mathrm{M}, 5$ to 10 times higher than their minimum inhibitory concentration.
\end{abstract}

Keywords: antimicrobial peptide; haemocyte; Sepia officinalis; mollusc; challenge; in vitro; Vibrio splendidus

\section{Introduction}

Antimicrobial peptides (AMPs) are small peptides commonly ranging from 10 to 50 amino acids in length and displaying activity against bacteria [1-3], viruses [4,5], fungi [6,7] or protozoan parasites [8,9]. Most of AMPs are cationic, but some anionic peptides have been identified too [10]. They are secreted by various cell types in a wide diversity of animal species [11], plants [12] and microorganisms [13], and derive from a precursor. Three main types of precursors are described: (1) precursors composed of a signal peptide followed by the mature AMP, like cecropins [14] or 
penaeidins [15], (2) precursors composed of a propeptide located between the signal peptide and the mature AMP, like cathelicidins [16] or hepcidins [17], or (3) precursors composed of the mature AMP located between the signal peptide and a C-terminal extension, like piscidins [18] or myticalins [19].

Molluscan species only rely on innate immune processes, including secretion of AMPs, to protect themselves against external aggressions [20]. Most of molluscan AMPs have been identified in the haemolymph and/or in the circulating cells-haemocytes (hct) -in bivalve species [1,21-30]. In many cases, AMPs were identified following bacterial challenge, e.g., mytilin A in the mussel Mytilus edulis [30], two isoforms of defensin (Cg-defh1 and Cg-defh2) [21] and a proline-rich AMP (Cg-Prp) [22] in the oyster Crassostrea gigas, big defensins Vp-BD in the clam Venerupis philippinarum [31] and Sb-BDefd-1 in the ark clam Scapharca broughtonii [28], myticusin-1 in Mytilus coruscus [29] and PmAMP-1 in the oyster Pinctada fucata martensii [26]. In other cases, differential expression of AMPs was observed following bacterial challenge, like overexpression of defensins in Mytilus galloprovincialis [23], big defensins in C. gigas [24], Pv-Def in the mussel Perna viridis [25] or downregulation of Cg-defh2 in C. gigas [21] or of penaeidins 3 and 5 in Fenneropenaeus chinensis [32]. In Gastropods, a few AMPs have been identified from the haemolymph and/or hct, including a proline-rich peptide from the marine snail Repana venosa [33] and defensin from the disk abalone Haliotis discus discus, whose expression in hct increased following bacterial challenge [34]. In Cephalopods, no AMP has been identified using classical approaches such as homology search using in silico analysis or immune challenge response. The only two AMPs described were designed in silico using a cuttlefish (Sepia officinalis) transcriptomic database including central nervous system, reproductive tissues and posterior salivary glands extracts, but no hct extract [35].

In this context, we studied the immune response of cuttlefish hct. Considering that cuttlefish belongs to animals subjected to directive 2010/63/EU on animal care and protection, an in vitro challenge was developed. The strain used for the challenge was Vibrio splendidus, which belongs to the Splendidus clade. Its members are known pathogens of octopus [36] as well as of shellfish hatcheries [37,38] or fish farms [39,40]. In silico analysis of de novo hct transcriptomes did not reveal any AMP based on homology or conserved patterns, so an in-depth in silico study was conducted on the differentially expressed transcripts of control versus challenged hct and AMP precursor characteristics such as the presence of a peptide signal and sequence length.

\section{Results-Discussion}

The two transcriptomes of control hct (c-hct) and V. splendidus-challenged hct (Vs-hct) comprised 96,765 (c-hct) and 107,747 (Vs-hct) transcript sequences including isoforms of 88,346 (c-hct) and 98,434 (Vs-hct) genes (according to the "gene" definition provided by Trinity assembler), with average lengths of 806.1 (c-hct) and 774.7 ( $V$ s-hct) nucleotides, respectively. Based on the presence of a blastx hit against the Uniprot-Swissprot database, $15 \%$ and $14 \%$ of all transcripts included in the c-hct and $V s$-hct transcriptomes, respectively, were annotated. These low levels of annotation are striking but commonly observed in such an atypical model, as already reported for the white body (WB) with $20 \%$ [41], the central nervous system (CNS) with $28 \%$ [42], the accessory nidamental gland (ANG) with $34 \%$, or the posterior salivatory gland (PSG) with $45 \%$ [43]. Besides, in another cephalopod species (Octopus vulgaris), $18.95 \%$ of the hct transcriptome was annotated [44]. These low levels of annotation reflect the lack of available data for cephalopod species and the need for further studies on unannotated transcripts.

Regarding the transcripts per kilobase million (TPM) values obtained during sequencing, the twenty most expressed transcripts (top20) in c-hct corresponded to transferrin, neurofilament, chitin deacetylase, structural polyprotein, polyubiquitin, tropomyosin, filamin-A, dynein light chain, ferritin, matrilin-2 and 3, matrix metalloproteinase, actin, riboflavin kinase, perivitellin, and five unannotated transcripts (Table S1). The top20 in Vs-hct corresponded to transferrin, neurofilament, chitin deacetylase, structural polyprotein, filamin-A, polyubiquitin, riboflavin kinase, histone H1, tropomyosin, ferritin, actin, perivitellin, dynein light chain, matrix metalloproteinase, matrilin-3, and five unannotated 
transcripts (Table S2). Eighteen of the c-hct top20 also belonged to the $V$ s-hct top20. Unknown 5 and matrilin-2 from the c-hct top20 were not part of the $V s$-hct top20, while histone H1 and unknown 6 from the $V s$-hct top20 were not in the c-hct top20. Comparing the global fold changes in TPM values between $V s$-hct and c-hct, $49 \%$ of the transcripts seemed up-regulated (fold change $>1.1$ ), $47 \%$ seemed down-regulated (fold change $<0.9$ ) and $4 \%$ seemed unaffected by the challenge $(0.9 \leq$ fold change $\leq$ 1.1). Several transcripts from both top20s were unaffected by the challenge, such as transferrin and chitin deacetylase whose fold changes were 0.98 and 0.93 , respectively. Furthermore, four transcripts from both top20s were up-regulated, namely unknowns 1 and 2, riboflavin kinase and perivitelline, with fold changes of 1.66, 1.35, 1.36 and 1.11, respectively. Twelve transcripts from both top20s were down-regulated, namely neurofilament, structural polyprotein, polyubiquitin, filamin-A, ferritin, tropomyosin, unknowns 3 and 4, matrix metalloproteinase, actin, matrilin-3 and dynein light chain, with fold changes of $0.87,0.72,0.69,0.85,0.60,0.81,0.60,0.84,0.56,0.82,0.56$ and 0.78 , respectively. The two transcripts only found in the $V s$-hct top20-histone $\mathrm{H} 1$ and unknown 6-were up-regulated by the bacterial challenge, with fold changes of 2.00 and 1.25 , respectively. Besides, the two transcripts only found in the c-hct top20-matrilin-2 and -5-were down-regulated, with fold changes of 0.44 and 0.42 , respectively (Tables S1 and S2). Interestingly, all unannotated transcripts of the c-hct and Vs-hct top20s seemed affected by the challenge with $V$. splendidus, highlighting the need for further analysis on unannotated sequences. Among the transcripts from both top20s affected by V. splendidus exposure, several (polyubiquitin, ferritin, paramyosin and actin) were differentially expressed after bacterial challenge of Ruditapes decussatus [45]. Interestingly, actin, which is commonly used as a reference gene, was affected by $V$. splendidus exposure, as previously reported for R. decussatus [45] and Mya arenaria $[46,47]$. The transcript annotated as transferrin coded for a partial sequence sharing sequence identity with salmon (Oncorhynchus kisutch) transferrin-like protein (41.16\%, P79815.1). Transferrins bind to iron and limit its availability by creating a bacteriostatic environment for iron-dependent bacteria. For example, Ab-transferrin was up-regulated upon immune stimulation of Haliotis discus discus with Vibrio parahaemolyticus, lipopolysaccharides and Listeria monocytogenes [48]. Additionally, the transcript coding for a homologue of histone $\mathrm{H} 1$ (So-H1) was up-regulated after bacterial challenge. Several antibacterial peptides derived from histone $\mathrm{H} 1$ have been described in salmon [49] and rainbow trout [50]. So-transferrin was highly expressed in both control and challenged conditions, and So-H1 expression was two-fold higher after challenge with $V$. splendidus. Therefore, it could be involved in the immune response.

Among the transcripts overexpressed in $V s$-hct, several were involved in the immune response, such as members of the Toll/NF-kB pathway (Table 1 ).

A Toll-like receptor (TLR) previously identified in ANG and called So-TLR $\gamma$ [51] was also identified in the two hct transcriptomes during this work, together with another sequence corresponding to a partial sequence of a TLR and called So-TLR-h. Partial So-TLR-h possessed leucine-rich repeat domains, one leucine-rich repeat C-terminal domain, a transmembrane domain and the Toll-interleukin-1 resistance domain, and shared $40.41 \%$ sequence identity with TLR-3 from $M$. corruscus whose expression was significantly higher in hct, digestive gland and adductor muscle than in foot [52]. Regarding TPM values, So-TLR $\gamma$ and So-TLR-h were up-regulated after incubation with V. splendidus, with fold changes of 1.29 and 15.11, respectively. Several molluscan TLRs were found up-regulated after immune challenge [44,53-56], confirming their function in the immune response. In addition, one inhibitor of NF-KB kinase (So-IKK-h) sharing 27.29\% sequence identity with Cyclina sinensis IKK (ASE55486.1) and one Rel/NF-kB (So-Rel/NF-kB-h) sharing 78.57\% sequence identity with Euprymna scolopes Rel/NF-кB (AAY27981.1) and possessing the Rel identity domain (RHD) were newly identified in the hct transcriptome. The myeloid differentiation primary response protein MyD88, the interleukin-1 receptor-associated kinase 4 (So-IRAK4), the TNF receptor-associated factor 6 (So-TRAF6) and the inhibitor of NF-kB (So-IKB) previously described in ANG [51] were also identified. All these factors could be involved in signal recognition and transduction leading to activation of immune gene transcription. Except $S o-I \kappa B$, all members of the Toll/NF-kB pathway identified in the present study 
were up-regulated after incubation with $V$. splendidus. These results are consistent with those obtained in M. galloprovincialis where almost all identified members of the Toll/NF- $\mathrm{B}$ pathway were up-regulated after challenge with several bacteria, including V. splendidus [56].

Table 1. Immune-related transcripts identified in the hct transcriptomes.

\begin{tabular}{|c|c|c|c|c|c|c|}
\hline \multirow{2}{*}{ Transcript } & \multirow{2}{*}{ Name } & \multirow{2}{*}{$\begin{array}{l}\text { Transcript } \\
\text { Length (nt) }\end{array}$} & \multirow{2}{*}{$\begin{array}{c}\text { Protein } \\
\text { Length (aa) }\end{array}$} & \multicolumn{2}{|c|}{ Expression (TPM) } & \multirow{2}{*}{$\begin{array}{c}\text { Fold } \\
\text { Change }\end{array}$} \\
\hline & & & & c-hct & Vs-hct & \\
\hline TR5906|c0_g1_i2 & TLR $\gamma$ & 2861 & 833 & 3.55 & 4.58 & 1.29 \\
\hline TR31922|c0_g2_i3 & TLR-h (partial) & 1741 & 536 & 0.31 & 4.71 & 15.11 \\
\hline TR20767|c0_g1_i1 & MyD88 & 1938 & 338 & 12.13 & 14.50 & 1.20 \\
\hline TR42010|c1_g1_i1 & IRAK4 & 1939 & 319 & 8.56 & 10.63 & 1.24 \\
\hline TR37884|c0_g2_i2 & TRAF6 & 2364 & 547 & 2.53 & 3.05 & 1.21 \\
\hline TR17535|c0_g1_i1 & IкB & 2609 & 337 & 233.96 & 230.08 & 0.98 \\
\hline TR34670|c0_g1_i1 & IKK-h & 2724 & 476 & 10.64 & 12.29 & 1.16 \\
\hline TR41212|c6_g1_i2 & Rel/NF-kB-h & 2614 & 491 & 1.85 & 2.56 & 1.39 \\
\hline TR24628|c0_g1_i1 & iNOS-h (partial) & 4137 & 1106 & 0.00 & 0.52 & - \\
\hline TR41722|c24_g56_i1 & PGRP-h1 & 873 & 213 & 254.12 & 466.71 & 1.84 \\
\hline TR14900|c0_g1_i1 & PGRP-h2 & 956 & 204 & 87.28 & 154.73 & 1.77 \\
\hline TR40338|c3_g2_i1 & BPI/LPB & 2342 & 537 & 134.38 & 149.31 & 1.11 \\
\hline TR32087|c0_g2_i1 & Gal-2 (partial) & 817 & 236 & 86.15 & 120.87 & 1.40 \\
\hline
\end{tabular}

aa: amino acid, nt: nucleotide, TPM: transcripts per kilobase million.

Immune factors were also identified, such as two peptidoglycan recognition proteins (So-PGRP-h1 and So-PGRP-h2), one bactericidal permeability-increasing protein/lipopolysaccharide-binding protein (So-BPI/LBP), one galectin (So-Gal-2) and a partial sequence of inducible nitric oxide synthase (So-iNOS-h) (Table 1). NOSs are known to produce nitric oxide (NO), which is involved in various physiological functions but could also kill bacteria when produced at high concentrations. So-iNOS-h shared $45.40 \%$ sequence identity with C. gigas NOS (K1QRH7), which was up-regulated in oyster hct after co-stimulation with LPS and TNF- $\alpha$ [57]. Both So-PGRP-h1 and So-PGRP-h2 identified in the hct transcriptomes possessed the conserved peptidoglycan-binding type-2 amidase domain, characteristic of vertebrate and invertebrate PGRPs. PGRPs are involved in various immune processes such as recognition, signalling and effector function [58]. They were up-regulated in Argopecten irradians after exposure to peptidoglycans [59] and in Chlamys farreri after exposure to V. anguillarum and Micrococcus lysodeikticus [60]. So-BPI/LBP, previously identified in cuttlefish WB [41], shares 52.58\% sequence identity with E. scolopes LBP-3 (AEL03862.1) and 30\% sequence identity with C. gigas LBP/BPI (AAN84552.1), whose recombinant protein possesses antibacterial activity against Escherichia coli strains [61]. Finally, partial sequence of So-Gal-2 previously identified in cuttlefish WB [41], which shares 46\% sequence identity with galectin-2-2 (AJA37869.1) identified in the Littorina littorea hct transcriptome [62] was identified in cuttlefish hct. TPM values showed that all these immune-related factors seemed up-regulated with fold change greater than 1.10 (Table 1). Three of them (So-Gal-2, So-PGRP-h1 and So-PGRP-h2) displayed "challenged" TPM values close to or more than 1.5-fold higher than control TPM values. Besides, So-iNOS had a TPM value of 0 in the control condition versus 0.52 in the challenged condition, suggesting $V$. splendidus-induced expression. All these data tend to confirm that the in vitro challenge performed in this study triggered the immune response of cuttlefish hct.

Our annotation-based search did not identify any AMP, so we performed an in-depth search based on unannotated transcripts, as described in Figure 1. 


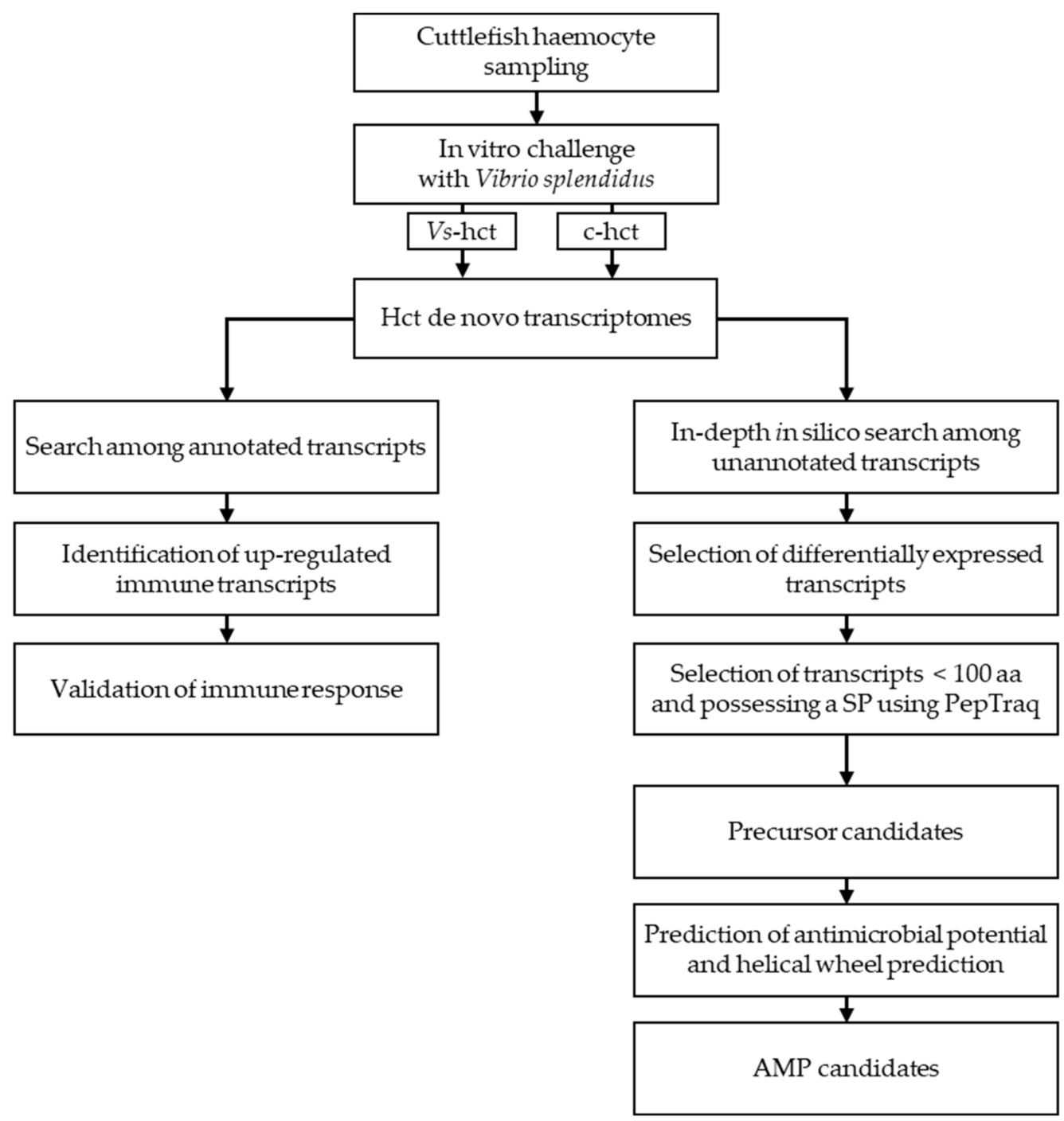

Figure 1. Overview of the methodology used to identify antimicrobial peptides using an in vitro challenge followed by an in-depth in silico search. AMP: antimicrobial peptides.

Among the differentially expressed transcripts between the control and challenged conditions, we selected sequences of less than 100 amino acids presenting a signal peptide, using our homemade PepTraq software program. We applied some of the specific structural AMP criteria previously defined by Houyvet and collaborators [35] and selected five candidates (Table 2).

Table 2. Putative AMP precursors identified in the hct transcriptomes.

\begin{tabular}{cccccccc}
\hline \multirow{2}{*}{ Transcript Name } & \multirow{2}{*}{ Length (aa) } & \multicolumn{2}{c}{ Expression (TPM) } & \multirow{2}{*}{ Fold Change } & \multirow{2}{*}{ SP } & \multirow{2}{*}{ AMP Name } \\
\cline { 3 - 4 } & & c-hct & Vs-hct & & & \\
\hline TR42258|c1_g1_i1 & 54 & $\mathbf{8 . 9 2}$ & 7.57 & & 0.85 & Yes & AV19 \\
\hline TR27534|c0_g1_i1 & 48 & 17.39 & $\mathbf{2 3 . 7 9}$ & 1.37 & Yes & GK28 \\
\hline TR36613|c0_g1_i1 & 47 & $\mathbf{2 0 . 2 8}$ & 17.01 & 0.84 & Yes & NF19 \\
\hline TR42563|c7_g3_i1 & 40 & $\mathbf{1 . 9 9}$ & 0.78 & 0.39 & Yes & II19 \\
\hline TR5654|c0_g1_i1 & 45 & 9.77 & $\mathbf{1 7 . 3 3}$ & 1.77 & Yes & LV25 \\
\hline
\end{tabular}

aa: amino acid, TPM: transcripts per kilobase million, SP: signal peptide. 
Among them, three were down-regulated after $V$. splendidus exposure, with fold changes of $0.39,0.84$ and 0.85 . The other two candidates were up-regulated with fold changes of 1.37 and 1.77. Expression values of these transcripts were also obtained for ink sac (male and female), embryo and skin (Table S3). These tissues are known to possess antimicrobial activities, as previously reported in Cephalopods for ink [63] and skin co-products [64,65]. One transcript-TR42563|c7_g3_i1—was almost exclusively expressed in hct. All the other transcripts were expressed in all samples. However, TR27534|c0_g1_i1 was more expressed in hct and skin. The complete sequences of the precursors are presented in Figure 2. The five precursors were between 40 and 54 amino acids in length, and all possessed a signal peptide.

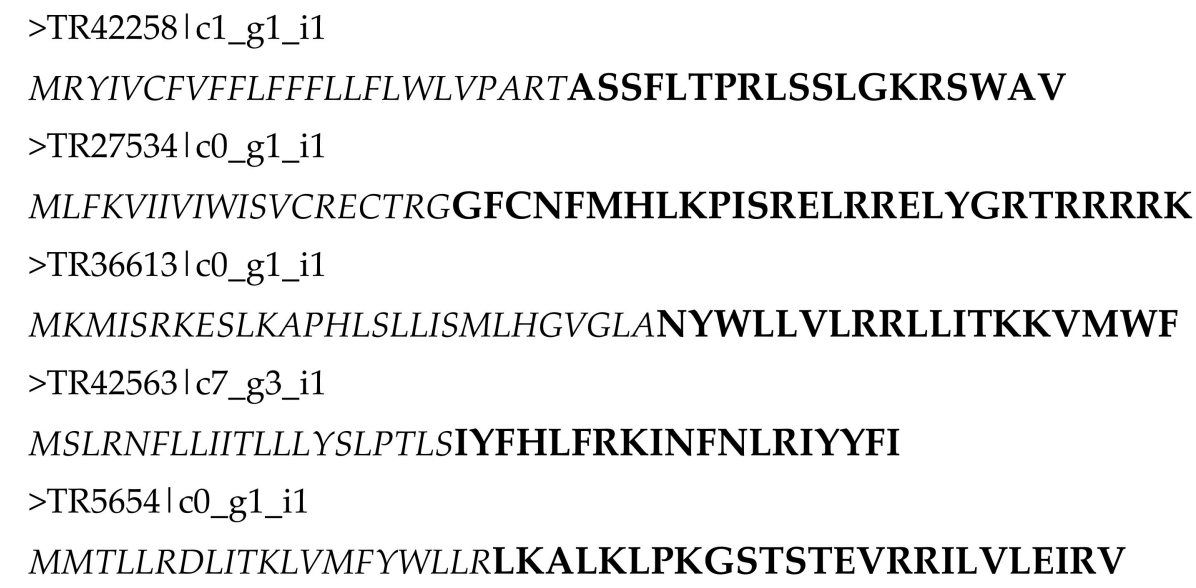

Figure 2. Protein sequences of putative AMP precursors (in italic: predicted signal peptide).

The peptides resulting from the selected precursors were between 19 and 28 amino acids in length, with molecular weights ranging from 2,063.38 to 3,577.25 Da. All peptides were cationic, with net charges ranging between +3 and +8 , and hydrophobic ratios ranging between $28 \%$ and $63 \%$ (Table 3 ).

Table 3. Peptide characteristics of the selected candidates.

\begin{tabular}{|c|c|c|c|c|c|c|c|c|c|c|}
\hline \multirow{2}{*}{ Name } & \multirow{2}{*}{ Sequence } & \multirow{2}{*}{$\begin{array}{l}\text { Length } \\
\text { (aa) }\end{array}$} & \multirow{2}{*}{ MW } & \multirow{2}{*}{$\mathrm{C}$} & \multirow{2}{*}{ HR } & \multirow{2}{*}{$\begin{array}{c}\alpha \text {-Helix } \\
\text { Prediction } \\
\text { and NRH }\end{array}$} & \multicolumn{4}{|c|}{ CAMP Algorithms } \\
\hline & & & & & & & SVM & RFC & ANN & DAC \\
\hline AV19 & ASSFLTPRLSSLGKRSWAV & 19 & 2063.38 & +3 & $42 \%$ & Yes-2 & 0.75 & 0.8 & AMP & 0.91 \\
\hline GK28 & $\begin{array}{c}\text { GFCNFMHLKPISRELRRELYGRTR } \\
\text { RRRK }\end{array}$ & 28 & 3577.25 & +8 & $28 \%$ & No & 0.69 & 0.31 & AMP & 0.8 \\
\hline NF19 & NYWLLVLRRLLITKKVMWF & 19 & 2493.14 & +4 & $63 \%$ & Yes-7 & 0.43 & 0.71 & AMP & 0.65 \\
\hline II19 & IYFHLFRKINFNLRIYYFI & 19 & 2581.1 & +3 & $52 \%$ & Yes-6 & 0.13 & 0.65 & AMP & 0.87 \\
\hline LV25 & LKALKLPKGSTSTEVRRILVLEIRV & 25 & 2820.45 & +4 & $44 \%$ & Yes-4 & 0.68 & 0.88 & NAMP & 0.84 \\
\hline
\end{tabular}

aa: amino acid, MW: molecular weight (Dalton), C: charge, HR: hydrophobic ratio, NRH: number of residues in the same hydrophobic surface, SVM: Support vector machine classifier, RFC: random forest classifier, ANN: artificial neural network, DAC: discriminant analysis classifier.

Using the Antimicrobial Peptide Database website's predictor (APD3), four of these five peptides were predicted to form an $\alpha$-helix possessing 2 to 7 residues in the same hydrophobic surface. Helical wheel projection from HeliQuest demonstrating that these four peptides adopted an $\alpha$-helix conformation and possessed a hydrophobic face (Figure 3). 

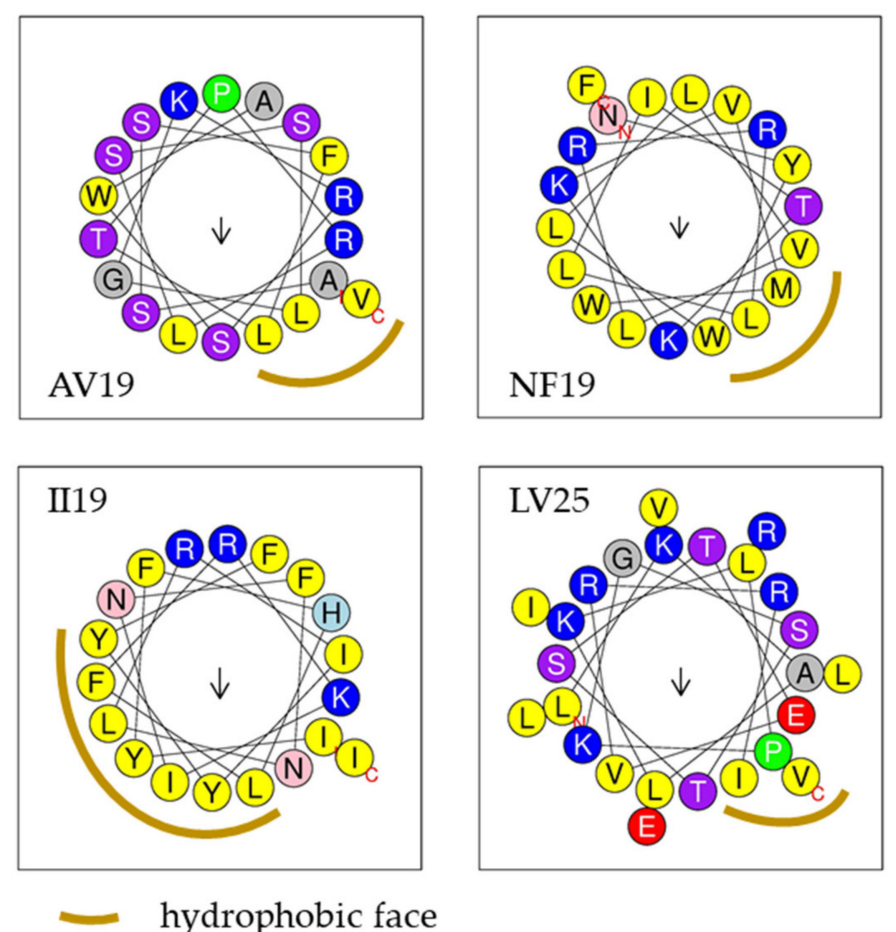

Figure 3. Helical wheel projections of AV19, NF19, II19 and LV25 predicted by the online tool HeliQuest. Yellow: hydrophobic residues; blue: basic residues; green: special residues; red: acidic residues; purple and pink: polar residues; arrow: hydrophobic moment.

The similarity of the five peptides with other known peptides was assayed using APD3 alignment program. AV19 possessed 40\% similarity with two frog antibacterial peptides, namely temporin-1Cd from Rana clamitans [66] and temporin-1Ola from $R$. akaloosae [67]. GK28 possessed 35.48\% similarity with marmelittin from the venom of the scorpion Mesobuthus eupeus [68] and a C-terminal end similar to the one of GR21 [35], in addition to the lowest hydrophobic ratio and the highest net charge of the selected peptides. Both NF19 and II19 possessed similarity with AMPs from the bovine rumen microbiome- $47.36 \%$ with P20 and 41.66\% with lynronne-2, respectively [69]. Finally, LV25 possessed $37.93 \%$ similarity with human peptide 6 [70].

The antimicrobial potential of the five peptides was assayed on ten bacteria-8 Gram-negative ones and 2 Gram-positive ones-i.e., $V$. splendidus, a cuttlefish pathogen $V$. alginolyticus [71], other aquatic pathogens $V$.anguillarum [72], Aeromonas salmonicida [73], Lactococcus garvieae [74] and V. parahaemolyticus causing human seafood-related illness [75]. Among the five peptides tested, three-AV19, GK28 and NF19-were active against at least one bacterial species (Table 4), whereas II19 and LV25 were not active against any bacterial species. None of the five peptides was active against Gram-positive bacteria. The three active peptides were all active against $V$. splendidus. NF19 inhibited $V$. splendidus growth between 5 and $10 \mu \mathrm{M}$ and was bactericidal between 10 and $20 \mu \mathrm{M}$. While its closest homologue P20 from the rumen microbiome was only semi-active against epidemic meticillin-resistant Staphylococcus aureus (EMRSA-15) [69], NF19 was strongly active against $V$. splendidus but did not show any activity against Gram-positive bacteria. AV19 inhibited both V. splendidus and V. parahaemolyticus between 10 and $20 \mu \mathrm{M}$ and was bactericidal between 10 and $20 \mu \mathrm{M}$ and 20 and $50 \mu \mathrm{M}$, respectively. Both frog temporins 1-Cd and 1Ola - the closest homologues of AV19-were active against S. aureus, and also against Bacillus subtilis for temporin-1Ola, but not against E. coli $[66,76]$, showing possible Gram-positive selectivity. As for AV19, it seemed active only against some Vibrio species. 
Table 4. Antimicrobial activity of the synthetic peptides.

\begin{tabular}{|c|c|c|c|c|c|c|c|c|c|c|c|c|c|c|c|c|c|c|c|c|}
\hline \multirow{3}{*}{ Name } & \multicolumn{16}{|c|}{ Gram Negative } & \multicolumn{4}{|c|}{ Gram Positive } \\
\hline & \multicolumn{2}{|c|}{$\begin{array}{c}\text { Vibrio } \\
\text { alginolyticus }\end{array}$} & \multicolumn{2}{|c|}{$\begin{array}{c}\text { Vibrio } \\
\text { splendidus }\end{array}$} & \multicolumn{2}{|c|}{$\begin{array}{c}\text { Vibrio } \\
\text { aestueranius }\end{array}$} & \multicolumn{2}{|c|}{$\begin{array}{c}\text { Vibrio } \\
\text { anguillarum }\end{array}$} & \multicolumn{2}{|c|}{$\begin{array}{c}\text { Vibrio } \\
\text { parahaemo-lyticus }\end{array}$} & \multicolumn{2}{|c|}{ Escherichia coli } & \multicolumn{2}{|c|}{$\begin{array}{l}\text { Halomonas } \\
\text { aquamarina }\end{array}$} & \multicolumn{2}{|c|}{$\begin{array}{l}\text { Aeromonas } \\
\text { salmonicida }\end{array}$} & \multicolumn{2}{|c|}{$\begin{array}{l}\text { Enterococcus } \\
\text { faecalis }\end{array}$} & \multicolumn{2}{|c|}{$\begin{array}{c}\text { Lactococcus } \\
\text { garvieae }\end{array}$} \\
\hline & MIC & MBC & MIC & MBC & MIC & MBC & MIC & МBC & MIC & MBC & MIC & МBC & MIC & MBC & MIC & MBC & MIC & МBC & MIC & MBC \\
\hline AV19 & - & - & $10-20$ & $10-20$ & - & - & - & - & $10-20$ & $20-50$ & - & - & - & - & - & - & - & - & - & - \\
\hline GK28 & $\leq 5$ & $20-50$ & $\leq 5$ & $\leq 5$ & $10-20$ & $>50$ & $10-20$ & $20-50$ & $\leq 5$ & $10-20$ & $\leq 5$ & $20-50$ & - & - & - & - & - & - & - & - \\
\hline NF19 & - & - & $5-10$ & $10-20$ & - & - & - & - & - & - & - & - & - & - & - & - & - & - & - & - \\
\hline II19 & - & - & - & - & - & - & - & - & - & - & - & - & - & - & - & - & - & - & - & - \\
\hline LV25 & - & - & - & - & - & - & - & - & - & - & - & - & - & - & - & - & - & - & - & - \\
\hline SYN & $10-20$ & $>20$ & 5-10 & $10-20$ & - & - & - & - & - & - & - & - & - & - & - & - & - & - & - & - \\
\hline Ox & $\leq 5$ & $\leq 5$ & $\leq 5$ & $\leq 5$ & $\leq 5$ & $\leq 5$ & $\leq 5$ & $\leq 5$ & $\leq 5$ & $\leq 5$ & $\leq 5$ & $\leq 5$ & $>10$ & - & $\leq 5$ & $\leq 5$ & $\leq 5$ & $5-10$ & $\leq 5$ & $>10$ \\
\hline
\end{tabular}


Only one peptide-GK28-was active against the five Vibrio species. GK28 inhibited the growth of $V$. alginolyticus, $V$. splendidus and $V$. parahaemolyticus equally as the positive control oxytetracycline did at concentrations $\leq 5 \mu \mathrm{M}$ and was also equally bactericidal against $V$. splendidus. In contrast to marmelittin-its closest homologue active against a broad range of Gram-negative and Gram-positive bacteria [68] - GK28 seemed only active against Gram-negative bacteria. GK28 was the only peptide active against a non-Vibrio species, i.e., E. coli. None of the five peptides was active against the other two Gram-negative bacteria Halomonas aquamarina and A. salmonicida (Table 4). The potential synergistic antibacterial activity of the active peptides and of the two up-regulated peptides-GK28 and LV25-was assayed. No synergistic activity was observed between the two most expressed peptides. Neither NF19 nor AV19 improved the antimicrobial activity of GK28. However, while AV19 and NF19 only delayed $V$. alginolyticus growth when tested alone (data not shown), a synergistic activity was observed when they were tested together (Table 4). No synergistic activity of NF19 and AV19 was observed against $V$. splendidus.

To test the toxicity of the newly identified peptides on eukaryotic cells, their haemolytic activity was assayed on human red blood cells (Figure 4).

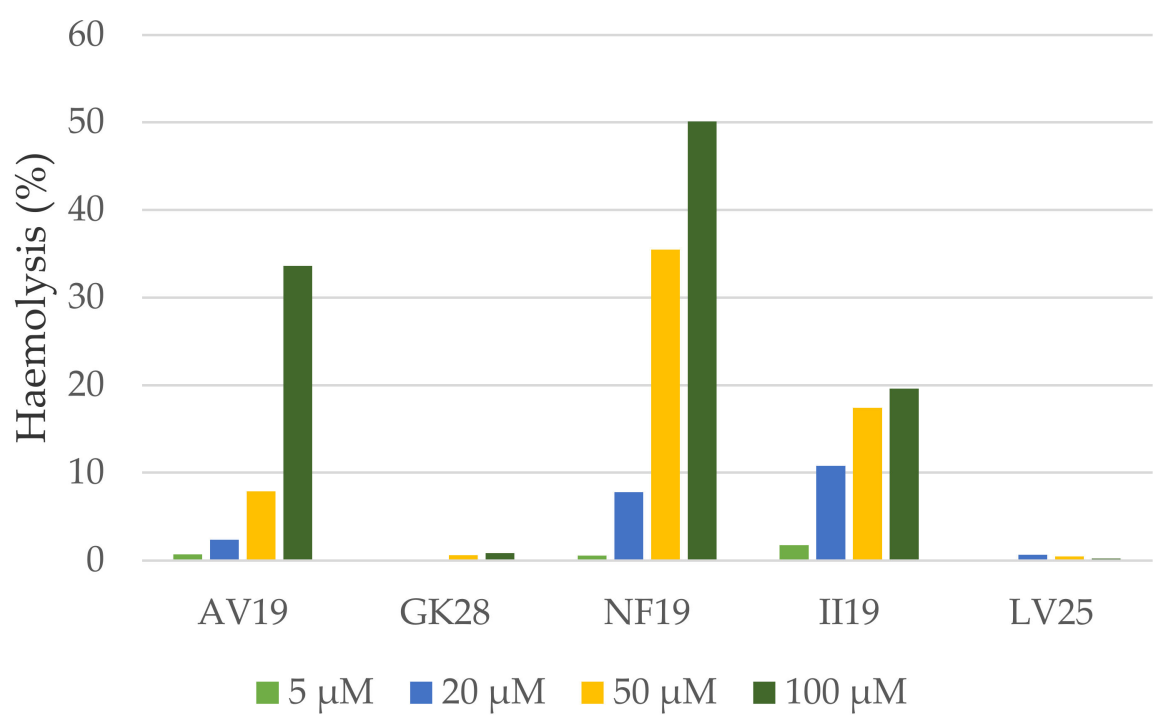

Figure 4. Haemolytic activity of the selected peptides on human red blood cells.

At the lowest concentration tested- $5 \mu \mathrm{M}-$, no haemolytic activity was observed for any of the five peptides. GK28 and LV25 were not haemolytic at any of the concentrations tested. AV19 was slightly haemolytic at 5, 20 and $50 \mu \mathrm{M}$, and induced 33\% haemolysis at $100 \mu \mathrm{M}$. II19 induced $11 \%, 17 \%$ and 19\% haemolysis at 20,50 and $100 \mu \mathrm{M}$, respectively. Finally, NF19 was the most haemolytic peptide: it induced 35 and $50 \%$ haemolysis at 50 and $100 \mu \mathrm{M}$, respectively. The most active peptide-GK28-was not haemolytic at any concentration whereas its closest homologue marmelittin is highly haemolytic on mouse, bird and lizard erythrocytes [68].

Three peptides possessing antibacterial activity were identified. NF19, AV19 and GK28 seemed to possess a complementary antibacterial activity, as observed with mussel myticalins [19]. Such complementarity may reflect the biological role of these AMPs in the cuttlefish immune response and need to be confirmed by in situ analysis. Out of the three active peptides, two were down-regulated by bacterial challenge and one was up-regulated. AMP down-regulation was previously observed in C. gigas hct: $C g$-defh 2 was down-regulated $24 \mathrm{~h}$ and $48 \mathrm{~h}$ post challenge with a heat-killed mix of Micrococcus luteus, V. splendidus and V. anguillarum, but up-regulated in the mantle and gills [21]. In $M$. galloprovincialis, myticin and mytilin were found down-regulated in hot after injection of heat-killed $V$. splendidus, while defensin was up-regulated. Moreover, after injection of heat-killed V. anguillarum, only mytilin was up-regulated while defensin and myticin seemed unaffected [77]. Similar results were 
obtained in shrimp in which Pen 3 and Pen 5 were down-regulated $24 \mathrm{~h}$ after injection of heat-killed $V$. anguillarum, while crustin and antilipopolysaccharide factor (ALF) were up-regulated [32]. Again, this may reflect the complementary activity of AMPs in the immune response. Finally, it is also interesting to note that the time lapse between bacterial exposure and the regulation of expression in hct varies greatly according to the AMP. For example, some AMPs are regulated rapidly: M. galloprovincialis defensin was up-regulated from $1 \mathrm{~h}$ after injection of heat-killed $V$. splendidus [77], Pinctada martensii AMP-1 was up-regulated $2 \mathrm{~h}$ after injection of a heat-killed mix of E. coli and M. luteus [26], or Scapharca broughtonii Sb-BDef1 was up-regulated $8 \mathrm{~h}$ and $16 \mathrm{~h}$ after injection of $V$. anguillarum [28]. Other AMPs are up-regulated late: $M$. coruscus myticusin- 1 expression peaked $36 \mathrm{~h}$ after injection of heat-killed $E$. coli [29], or C. gigas Cg-BigDef1 was up-regulated $24 \mathrm{~h}, 48 \mathrm{~h}$ and $72 \mathrm{~h}$ after injection of $V$. splendidus and Vibrio tasmaniensis [24]. It would be interesting to study the time-course of the relative expression of the three AMPs NF19, AV19 and GK28 during bacterial challenge with different bacteria.

\section{Materials and Methods}

\subsection{Animals}

Healthy cuttlefish (Sepia officinalis) were caught in the Bay of the Seine between January and June 2015. They were maintained in 1000-L outflow tanks with a permanent water supply at the Centre de Recherches en Environnement Côtier (CREC, marine station of the University of Caen, Luc-sur-Mer, France). Water temperature was maintained at $16{ }^{\circ} \mathrm{C}$.

\subsection{Ethical Statement}

This research followed the guidance given by Directive 2010/63/EU and French regulations regarding the use of animals for experimental procedures. It was approved by the Regional Ethical Committee Cenomexa (Committee agreement number 54; project agreement number 03145.03). The experiment was designed to decrease animal distress by minimising the number of animals. Moreover, the tanks were modified so as to provide hiding places for cuttlefish.

\subsection{Haemolymph Collection and Challenge with Heat-Killed Bacteria}

Two female cuttlefish were anesthetised with ethanol 3\% before tissue collection. Haemolymph was withdrawn from the vena cava and branchial hearts using a $10 \mathrm{~mL}$ syringe. Vibrio splendidus strain CIP 107,715 was grown under agitation at $20^{\circ} \mathrm{C}$ in Marine Broth (Conda, $40.20 \mathrm{~g} / \mathrm{L}$ ) medium for $24 \mathrm{~h}$. The culture was centrifuged $(4,000 \times g, 5 \mathrm{~min}$, room temperature), washed twice, and resuspended in sterile sea water to an optical density at $600 \mathrm{~nm}\left(\mathrm{OD}_{600}\right)$ of $1\left(1 \times 10^{9} \mathrm{CUF} / \mathrm{mL}\right)$.

Haemolymph was diluted in sterile sea water $(v / v)$ and divided into two batches: $10 \mathrm{~mL}$ remained untreated, and $10 \mathrm{~mL}$ were challenged with $200 \mu \mathrm{l}$ of boiled bacteria (boiled $15 \mathrm{~min}$ at $100^{\circ} \mathrm{C}$ ). Haemolymph with and without heat-killed bacteria was then incubated at $16^{\circ} \mathrm{C}$ at $100 \mathrm{rpm}$ in a MaxQ6000 incubator (ThermoFisher) equipped with an orbital shaker. After $24 \mathrm{~h}$, hct from the two conditions were harvested by centrifugation at 12,000 rpm and resuspended in TriReagent (Sigma-Aldrich, Saint Louis, MO, USA) to extract total RNA.

\subsection{Illumina Sequencing}

RNA extractions were performed as described by Cornet and collaborators [43]. For sequencing, other samples than hct were used, namely ink sac, skin, and embryo. Total RNA concentrations were quantified using a NanoDrop spectrophotometer (ThermoFisher), and RNA quality was checked using a Bioanalyzer (Agilent Technologies). Library preparation and sequencing was conducted by the McGill University and Génome Québec Innovation Centre (Montréal, Québec, Canada) following the manufacturer's instructions (Illumina, San Diego, CA). The detailed protocol is available in the supporting experimental section.

Raw data are accessible under ENA project PRJEB39162. 


\subsection{Bioinformatic Analysis}

\subsubsection{Transcriptome Assembly}

Quality checks of raw data from the six libraries were performed with FastQC v. 0.11 .5 (https: //www.bioinformatics.babraham.ac.uk/projects/fastqc/). Low quality trimming was performed with Trimmomatic v. 0.36 [78] using the following parameters: leading 3, trailing 3, sliding window 4:15, minlen 30. Reads from all tissues were assembled de novo all together with Trinity v 2.2.0 [79] including the read normalisation step corresponding to the Trinity implementation of the diginorm method. The assembler was run with default parameters. The sequences from each library were aligned with RSEM [80] against de novo assembly.

\subsubsection{Transcriptome Annotation}

Peptide prediction was performed using Transdecoder 5.2.0 [81]. Similarity search (diamond v0.7.9) [82] of the Transdecoder predicted peptides was performed against the Uniprot-Swissprot databases and UniRef90 (release 2018). Peptide signal prediction was performed using SignalP v4.1 [83]. Transmembrane peptide detection was performed using TMHMM v2.0c [84]. Protein domain search was performed using hmmscan from the hmmer v.3.1b1 suite against the Pfam-A database (release 31.0) [85]. Finally, transcriptome functional annotation was performed using the Trinotate pipeline (http://trinotate.github.io described) [81]. An additional annotation-based search was conducted on the hct transcriptomes (c-hct and Vs-hct) searching for relevant immune-related transcripts and AMPs. Specific domains were predicted using the online tool SMART (http://smart.embl-heidelberg.de/) [86].

\subsubsection{PepTraq}

PepTraq is a homemade software program developed to perform in silico analyses from "-omic" data (https://peptraq.greyc.fr). The search for precursors or peptides through PepTraq can be achieved using several structural criteria, as described by Zatylny-Gaudin and collaborators [42] for neuropeptides or by Houyvet and collaborators [35] for antibacterial peptides. The PepTraq version used for this work included new features with respect to previous ones, in particular (1) the prediction of Sec-dependent signal peptides, using package JSPP [87] and (2) the selection of sequences containing a certain number of occurrences of a given pattern (possibly including a number of unspecified amino acids).

\subsubsection{In-Depth In Silico Search}

In addition to an annotation-based search, we performed an in-depth in silico search using our homemade software PepTraq to look for AMPs. PepTraq is a useful tool developed to conduct in silico approaches on transcriptomic or proteomic datasets based on specific criteria (e.g., the presence of a signal peptide, sequence length, the occurrence and number of certain amino acids or specific patterns, the occurrence of consensus subsequences, the hydrophobicity degree, the electrical charge of protein sequences). The pipeline of the methodology used during this work is illustrated in Figure 1. We targeted unannotated transcripts differentially expressed between control and challenged conditions as well as the length of the resulting precursors and the presence of signal peptides. Among the selected precursors, we targeted some AMP characteristics, as previously described by Houyvet and collaborators [35]. The antimicrobial potential of the selected peptides was evaluated using the CAMP database website's prediction tool [88] (http://www.camp.bicnirrh.res.in/index.php). We selected the following four algorithms: Support Vector Machine (SVM), Random Forests (RF), Artificial Neural Network (ANN) and Discriminant Analysis (DA). The molecular weight (MW), the net charge, the hydrophobic ratio (HR), $\alpha$-helix prediction and the number of residues of the same hydrophobic surface of the selected peptides were calculated with the Antimicrobial Peptide Database (APD) website's calculator and predictor (APD3) [89] (http://aps.unmc.edu/AP/prediction/prediction_main.php). The helical 
wheel projection diagrams were predicted using Heliquest website's sequence analysis module [90] (https://heliquest.ipmc.cnrs.fr/cgi-bin/ComputParams.py).

\subsection{Peptide Synthesis}

The five selected peptides were synthesized by GENECUST (Dudelange, Luxembourg) with $>95 \%$ overall purity.

\subsection{Antimicrobial Assay}

The minimal growth inhibitory concentrations (MICs) of synthetic peptides (Genecust) were evaluated on Vibrio alginolyticus (CIP 109819), V. splendidus (CIP 107715), V. aestuerianus (CIP 102971), V. anguillarum (CIP 64.14), V. parahaemolyticus (CIP 73.30), Halomonas aquamarina (CIP 105454T), Escherichia coli (CIP 54.8T), Aeromonas salmonicida (CIP 103209T), Enteroccocus faecalis (CIP 76.117) and Lactococcus garvieae (CIP 104369) obtained from the "Collection de l'Institut Pasteur". Bacteria were cultured in adapted media: Homemade marine broth (HMB, sea salts $20 \mathrm{~g} / \mathrm{L}$, peptone $5 \mathrm{~g} / \mathrm{L}$, yeast extract $3 \mathrm{~g} / \mathrm{L}$ ) for Vibrio species and H. aquamarina; Luria-Bertani (peptone $10 \mathrm{~g} / \mathrm{L}$, yeast extract $5 \mathrm{~g} / \mathrm{L}, \mathrm{NaCl} 10 \mathrm{~g} / \mathrm{L}$ ) for E. faecalis and E. coli; Trypticasein Soy Broth (TSB, Conda, $40 \mathrm{~g} / \mathrm{L}$ ) for A. salmonicida, and Brain Heart Infusion (BHI) (Conda, $37 \mathrm{~g} / \mathrm{L}$ ) for L. garvieae. MICs were determined in triplicate by liquid growth inhibition assays adapted from Hetru and Bulet [91]. Briefly, $10 \mu \mathrm{L}$ of peptide solution were incubated in Bioscreen honeycomb-well plates with $90 \mu \mathrm{l}$ of bacterial suspension at a starting $\mathrm{OD}_{600}$ of 0.001 in BHI for L. garvieae, poor broth (peptone $10 \mathrm{~g} / \mathrm{L}, \mathrm{NaCl} 5 \mathrm{~g} / \mathrm{L}$ ) for E. faecalis and E. coli, TSB for A. salmonicida, HMB for H. aquamarina and saline poor broth (peptone $10 \mathrm{~g} / \mathrm{L}, \mathrm{NaCl} 15 \mathrm{~g} / \mathrm{L}$ ) for Vibrio species. Bacterial growth was monitored for $16 \mathrm{~h}$ by measuring $\mathrm{OD}_{600}$ values every $5 \mathrm{~min}$ (Bioscreen C, Labsystem, Finland). The peptides were tested alone at concentrations of $5 \mu \mathrm{M}, 10 \mu \mathrm{M}, 20 \mu \mathrm{M}$ and $50 \mu \mathrm{M}$. For synergy, peptides pairs were tested at concentrations of $5 \mu \mathrm{M}, 10 \mu \mathrm{M}$ and $20 \mu \mathrm{M}$. Oxytetracycline at $5 \mu \mathrm{M}$ and $10 \mu \mathrm{M}$ was used as a positive control, and water was used as a blank. MICs were expressed in $\mu \mathrm{M}$ as an [a]-[b] concentration interval where [a] was the last concentration with bacterial growth and [b] was the first concentration with $100 \%$ bacterial growth inhibition. MBCs (minimal bactericidal concentrations) were expressed in $\mu \mathrm{M}$ as an [a]-[b] concentration interval where [a] was the last concentration with bacterial growth and [b] was the first concentration that killed $100 \%$ of the bacteria [91].

\subsection{Haemolytic Assay}

The haemolytic activity of the synthetic peptides was determined in triplicate on human red blood cells (RBCs) as described by Duval and collaborators [92]. Briefly, RBCs were pelleted and washed three times in phosphate-buffered saline (PBS). Then, they were resuspended in PBS to obtain a $1 \%$ solution of RBC. Ten microliters of peptide solution were incubated with $90 \mu \mathrm{L}$ of the RBC $1 \%$ solution for $1 \mathrm{~h}$ at $37^{\circ} \mathrm{C}$. The peptides were diluted in PBS and tested at different concentrations: 5 $\mu \mathrm{M}, 20 \mu \mathrm{M}, 50 \mu \mathrm{M}$ and $100 \mu \mathrm{M}$. Haemolytic activity was determined by measuring the OD at 415 $\mathrm{nm}$. Zero haemolysis and total (100\%) haemolysis were determined with PBS and 1\% Triton X-100 solutions, respectively.

\section{Conclusions}

In vitro challenge with Vibrio splendidus was sufficient to trigger the immune response and the overexpression of members of the Toll/NF- $\mathrm{kB}$ pathway and other immune-related factors in cuttlefish haemocytes. As no annotated AMP was identified, we carried out an in-depth in silico search with PepTraq, based on specific characteristics and expression values between control and challenge conditions. This stringent methodology allowed us to select a small list of candidates, $60 \%$ of which displayed antibacterial activity. Three peptides displayed targeted activity against Vibrio species, and one of them-GK28 - was active at low concentrations and did not induce haemolysis of human red blood cells even at high concentrations. Considering that these three peptides were identified from a 
precursor with a signal peptide, it would be interesting to validate their biological function in cuttlefish. The methodology used in this study, based on Houyvet and collaborators [35] as an alternative to classical methods requiring a lot of biological material, was focused on the reduction of animal pain and use, consistent with directive 2010/63/EU on animal care and protection.

Supplementary Materials: The following are available online at http://www.mdpi.com/1660-3397/18/9/439/s1, Supporting experimental section. Table S1: Twenty most expressed transcripts in c-hct, Table S2: Twenty most expressed transcripts in Vs-hct. Table S3: Expression patterns of selected transcripts.

Author Contributions: The manuscript was written by L.B., with the following contributions from the other authors: C.Z.-G. played an important role in designing approaches and peptide selection. J.H. collected cuttlefish for the transcriptomic approach. B.H. performed in vitro assays on haemocytes. E.C. assembled and annotated the het transcriptomes. L.B. performed antimicrobial and haemolytic assays. B.Z. developed a new version of PepTraq in collaboration with J.H. and C.Z.-G. All authors have read and agreed to the published version of the manuscript.

Funding: We thank the "Région Normandie" for funding this work.

Acknowledgments: We thank the EFS (Etablissement Français du sang) for human blood samples. We are grateful to the Institut Français de Bioinformatique (ANR-11-INBS-0013) and the Roscoff Bioinformatics platform ABiMS (http://abims.sb-roscoff.fr) for providing help for computing and storage resources.

Conflicts of Interest: The authors declare no conflict of interest.

\section{References}

1. Mitta, G.; Hubert, F.; Noël, T.; Roch, P. Myticin, a novel cysteine-rich antimicrobial peptide isolated from haemocytes and plasma of the mussel Mytilus galloprovincialis. Eur. J. Biochem. 1999, 265, 71-78. [CrossRef]

2. Birkemo, G.A.; Lüders, T.; Andersen, $\varnothing$.; Nes, I.F.; Nissen-Meyer, J. Hipposin, a histone-derived antimicrobial peptide in Atlantic halibut (Hippoglossus hippoglossus L.). Biochim. Biophys. Acta BBA Proteins Proteom. 2003, 1646, 207-215. [CrossRef]

3. Gueguen, Y.; Herpin, A.; Aumelas, A.; Garnier, J.; Fievet, J.; Escoubas, J.-M.; Bulet, P.; Gonzalez, M.; Lelong, C.; Favrel, P.; et al. Characterization of a Defensin from the Oyster Crassostrea gigas. J. Biol. Chem. 2006, 281, 313-323. [CrossRef]

4. Robinson, W.E.; McDougall, B.; Tran, D.; Selsted, M.E. Anti-HIV-1 activity of indolicidin, an antimicrobial peptide from neutrophils. J. Leukoc. Biol. 1998, 63, 94-100. [CrossRef]

5. Vilas Boas, L.C.P.; de Lima, L.M.P.; Migliolo, L.; Mendes, G.D.S.; de Jesus, M.G.; Franco, O.L.; Silva, P.A. Linear antimicrobial peptides with activity against herpes simplex virus 1 and Aichi virus. Pept. Sci. 2017, 108, e22871. [CrossRef] [PubMed]

6. Fehlbaum, P.; Bulet, P.; Michaut, L.; Lagueux, M.; Broekaert, W.F.; Hetru, C.; Hoffmann, J.A. Insect immunity: Septic injury of drosophila induces the synthesis of a potent antifungal peptide with sequence homology to plant antifungal peptides. J. Biol. Chem. 1994, 269, 33159-33163. [PubMed]

7. Benincasa, M.; Scocchi, M.; Pacor, S.; Tossi, A.; Nobili, D.; Basaglia, G.; Busetti, M.; Gennaro, R. Fungicidal activity of five cathelicidin peptides against clinically isolated yeasts. J. Antimicrob. Chemother. 2006, 58, 950-959. [CrossRef] [PubMed]

8. Löfgren, S.E.; Miletti, L.C.; Steindel, M.; Bachère, E.; Barracco, M.A. Trypanocidal and leishmanicidal activities of different antimicrobial peptides (AMPs) isolated from aquatic animals. Exp. Parasitol. 2008, 118, 197-202. [CrossRef] [PubMed]

9. Brand, G.D.; Leite, J.R.S.A.; Silva, L.P.; Albuquerque, S.; Prates, M.V.; Azevedo, R.B.; Carregaro, V.; Silva, J.S.; Sá, V.C.L.; Brandão, R.A.; et al. Dermaseptins from Phyllomedusa oreades and Phyllomedusa distincta. Anti-Trypanosoma cruzi activity without cytotoxicity to mammalian cells. J. Biol. Chem. 2002, 277, 49332-49340. [CrossRef]

10. Harris, F.; Dennison, S.; Phoenix, D. Anionic Antimicrobial Peptides from Eukaryotic Organisms. Curr. Protein Pept. Sci. 2009, 10, 585-606. [CrossRef]

11. Jenssen, H.; Hamill, P.; Hancock, R.E.W. Peptide Antimicrobial Agents. Clin. Microbiol. Rev. 2006, 19, $491-511$. [CrossRef] [PubMed]

12. Stotz,H.U.; Waller, F.; Wang, K. Innate Immunity in Plants: The Role of Antimicrobial Peptides. In Antimicrobial Peptides and Innate Immunity; Springer: Basel, Switzerland, 2013; pp. 29-51. ISBN 9783034805414. 
13. Paiva, A.D.; Breukink, E. Antimicrobial Peptides Produced by Microorganisms. In Antimicrobial Peptides and Innate Immunity; Springer: Basel, Switzerland, 2013; pp. 53-95. ISBN 9783034805414.

14. Sun, D.; Eccleston, E.D.; Fallon, A.M. Cloning and expression of three cecropin cDNAs from a mosquito cell line. FEBS Lett. 1999, 454, 147-151. [CrossRef]

15. Destoumieux, D.; Bulet, P.; Loew, D.; Van Dorsselaer, A.; Rodriguez, J.; Bachère, E. Penaeidins, a New Family of Antimicrobial Peptides Isolated from the Shrimp Penaeus vannamei (Decapoda). J. Biol. Chem. 1997, 272, 28398-28406. [CrossRef] [PubMed]

16. Xiao, Y.; Cai, Y.; Bommineni, Y.R.; Fernando, S.C.; Prakash, O.; Gilliland, S.E.; Zhang, G. Identification and Functional Characterization of Three Chicken Cathelicidins with Potent Antimicrobial Activity. J. Biol. Chem. 2006, 281, 2858-2867. [CrossRef]

17. Douglas, S.E.; Gallant, J.W.; Liebscher, R.S.; Dacanay, A.; Tsoi, S.C.M. Identification and expression analysis of hepcidin-like antimicrobial peptides in bony fish. Dev. Comp. Immunol. 2003, 27, 589-601. [CrossRef]

18. Houyvet, B.; Bouchon-Navaro, Y.; Bouchon, C.; Goux, D.; Bernay, B.; Corre, E.; Zatylny-Gaudin, C. Identification of a moronecidin-like antimicrobial peptide in the venomous fish Pterois volitans: Functional and structural study of pteroicidin- $\alpha$. Fish Shellfish Immunol. 2017, 72, 318-324. [CrossRef]

19. Leoni, G.; De Poli, A.; Mardirossian, M.; Gambato, S.; Florian, F.; Venier, P.; Wilson, D.; Tossi, A.; Pallavicini, A.; Gerdol, M. Myticalins: A Novel Multigenic Family of Linear, Cationic Antimicrobial Peptides from Marine Mussels (Mytilus spp.). Mar. Drugs 2017, 15, 261. [CrossRef]

20. Gerdol, M.; Gomez-Chiarri, M.; Castillo, M.G.; Figueras, A.; Fiorito, G.; Moreira, R.; Novoa, B.; Pallavicini, A.; Ponte, G.; Roumbedakis, K.; et al. Immunity in Molluscs: Recognition and Effector Mechanisms, with a Focus on Bivalvia. In Advances in Comparative Immunology; Springer International Publishing: Cham, Switzerland, 2018; pp. 225-341, ISBN 9781461490654.

21. Gonzalez, M.; Gueguen, Y.; Desserre, G.; de Lorgeril, J.; Romestand, B.; Bachère, E. Molecular characterization of two isoforms of defensin from hemocytes of the oyster Crassostrea gigas. Dev. Comp. Immunol. 2007, 31, 332-339. [CrossRef]

22. Gueguen, Y.; Bernard, R.; Julie, F.; Paulina, S.; Delphine, D.-G.; Franck, V.; Philippe, B.; Evelyne, B. Oyster hemocytes express a proline-rich peptide displaying synergistic antimicrobial activity with a defensin. Mol. Immunol. 2009, 46, 516-522. [CrossRef]

23. Mitta, G.; Vandenbulcke, F.; Hubert, F.; Roch, P. Mussel defensins are synthesised and processed in granulocytes then released into the plasma after bacterial challenge. J. Cell Sci. 1999, 112, 4233-4242.

24. Rosa, R.D.; Santini, A.; Fievet, J.; Bulet, P.; Destoumieux-Garzón, D.; Bachère, E. Big Defensins, a Diverse Family of Antimicrobial Peptides That Follows Different Patterns of Expression in Hemocytes of the Oyster Crassostrea gigas. PLoS ONE 2011, 6, e25594. [CrossRef] [PubMed]

25. Wang, Y.; Zeng, Z.; Zhang, X.; Shi, Q.; Wang, C.; Hu, Z.; Li, H. Identification and characterization of a novel defensin from Asian green mussel Perna viridis. Fish Shellfish Immunol. 2018, 74, 242-249. [CrossRef] [PubMed]

26. He, J.; Liang, H.; Zhu, J.; Fang, X. Separation, identification and gene expression analysis of PmAMP-1 from Pinctada fucata martensii. Fish Shellfish Immunol. 2019, 92, 728-735. [CrossRef] [PubMed]

27. Yang, D.; Zhang, Q.; Wang, Q.; Chen, L.; Liu, Y.; Cong, M.; Wu, H.; Li, F.; Ji, C.; Zhao, J. A defensin-like antimicrobial peptide from the manila clam Ruditapes philippinarum: Investigation of the antibacterial activities and mode of action. Fish Shellfish Immunol. 2018, 80, 274-280. [CrossRef]

28. Li, M.; Zhu, L.; Zhou, C.; Sun, S.; Fan, Y.; Zhuang, Z. Molecular characterization and expression of a novel big defensin (Sb-BDef1) from ark shell, Scapharca broughtonii. Fish Shellfish Immunol. 2012, 33, 1167-1173. [CrossRef]

29. Liao, Z.; Wang, X.C.; Liu, H.H.; Fan, M.H.; Sun, J.J.; Shen, W. Molecular characterization of a novel antimicrobial peptide from Mytilus coruscus. Fish Shellfish Immunol. 2013, 34, 610-616. [CrossRef]

30. Charlet, M.; Chernysh, S.; Philippe, H.; Hetru, C.; Hoffmann, J.A.; Bulet, P. Isolation of Several Cystein-rich Antimicrobial Peptides from the Blood of a Mollusc, Mytilus edulis. J. Biol. Chem. 1996, 271, 21808-21813. [CrossRef]

31. Zhao, J.; Li, C.; Chen, A.; Li, L.; Su, X.; Li, T. Molecular Characterization of a Novel Big Defensin from Clam Venerupis philippinarum. PLoS ONE 2010, 5, e13480. [CrossRef]

32. Wang, D.; Li, F.; Li, S.; Wen, R.; Xiang, J. Expression profiles of antimicrobial peptides (AMPs) and their regulation by Relish. Chin. J. Oceanol. Limnol. 2012, 30, 611-619. [CrossRef] 
33. Dolashka, P.; Moshtanska, V.; Borisova, V.; Dolashki, A.; Stevanovic, S.; Dimanov, T.; Voelter, W. Antimicrobial proline-rich peptides from the hemolymph of marine snail Rapana venosa. Peptides 2011, 32, 1477-1483. [CrossRef]

34. De Zoysa, M.; Whang, I.; Lee, Y.; Lee, S.; Lee, J.-S.; Lee, J. Defensin from disk abalone Haliotis discus discus: Molecular cloning, sequence characterization and immune response against bacterial infection. Fish Shellfish Immunol. 2010, 28, 261-266. [CrossRef] [PubMed]

35. Houyvet, B.; Zanuttini, B.; Corre, E.; Le Corguillé, G.; Henry, J.; Zatylny-Gaudin, C. Design of antimicrobial peptides from a cuttlefish database. Amino Acids 2018, 50, 1573-1582. [CrossRef] [PubMed]

36. Farto, R.; Armada, S.P.; Montes, M.; Guisande, J.A.; Pérez, M.J.; Nieto, T.P. Vibrio lentus associated with diseased wild octopus (Octopus vulgaris). J. Invertebr. Pathol. 2003, 83, 149-156. [CrossRef]

37. Prado, S.; Dubert, J.; da Costa, F.; Martínez-Patiño, D.; Barja, J.L. Vibrios in hatchery cultures of the razor clam, Solen marginatus (Pulteney). J. Fish Dis. 2014, 37, 209-217. [CrossRef]

38. Rojas, R.; Miranda, C.D.; Opazo, R.; Romero, J. Characterization and pathogenicity of Vibrio splendidus strains associated with massive mortalities of commercial hatchery-reared larvae of scallop Argopecten purpuratus (Lamarck, 1819). J. Invertebr. Pathol. 2015, 124, 61-69. [CrossRef] [PubMed]

39. Pujalte, M.; Sitjà-Bobadilla, A.; Álvarez-Pellitero, P.; Garay, E. Carriage of potentially fish-pathogenic bacteria in Sparus aurata cultured in Mediterranean fish farms. Dis. Aquat. Organ. 2003, 54, 119-126. [CrossRef]

40. Lasa, A.; Avendaño-Herrera, R.; Estrada, J.M.; Romalde, J.L. Isolation and identification of Vibrio toranzoniae associated with diseased red conger eel (Genypterus chilensis) farmed in Chile. Vet. Microbiol. 2015, 179, 327-331. [CrossRef]

41. Benoist, L.; Corre, E.; Bernay, B.; Henry, J.; Zatylny-Gaudin, C. -Omic Analysis of the Sepia officinalis White Body: New Insights into Multifunctionality and Haematopoiesis Regulation. J. Proteome Res. 2020, 19, 3072-3087. [CrossRef]

42. Zatylny-Gaudin, C.; Cornet, V.; Leduc, A.; Zanuttini, B.; Corre, E.; Le Corguillé, G.; Bernay, B.; Garderes, J.; Kraut, A.; Couté, Y.; et al. Neuropeptidome of the Cephalopod Sepia officinalis: Identification, Tissue Mapping, and Expression Pattern of Neuropeptides and Neurohormones during Egg Laying. J. Proteome Res. 2016, 15, 48-67. [CrossRef]

43. Cornet, V.; Henry, J.; Corre, E.; Le Corguille, G.; Zanuttini, B.; Zatylny-Gaudin, C. Dual role of the cuttlefish salivary proteome in defense and predation. J. Proteom. 2014, 108, 209-222. [CrossRef]

44. Castellanos-Martínez, S.; Arteta, D.; Catarino, S.; Gestal, C. De novo transcriptome sequencing of the Octopus vulgaris hemocytes using illumina RNA-Seq technology: Response to the infection by the gastrointestinal parasite Aggregata octopiana. PLoS ONE 2014, 9, e107873. [CrossRef] [PubMed]

45. Gestal, C.; Costa, M.; Figueras, A.; Novoa, B. Analysis of differentially expressed genes in response to bacterial stimulation in hemocytes of the carpet-shell clam Ruditapes decussatus: Identification of new antimicrobial peptides. Gene 2007, 406, 134-143. [CrossRef] [PubMed]

46. Mateo, D.R.; Greenwood, S.J.; Araya, M.T.; Berthe, F.C.J.; Johnson, G.R.; Siah, A. Differential gene expression of $\gamma$-actin, Toll-like receptor 2 (TLR-2) and interleukin-1 receptor-associated kinase 4 (IRAK-4) in Mya arenaria haemocytes induced by in vivo infections with two Vibrio splendidus strains. Dev. Comp. Immunol. 2010, 34, 710-714. [CrossRef] [PubMed]

47. Araya, M.T.; Siah, A.; Mateo, D.R.; Markham, F.; McKenna, P.; Johnson, G.R.; Berthe, F.C.J. Morphological and Molecular Effects of Vibrio splendidus on Hemocytes of Softshell Clams, Mya arenaria. J. Shellfish Res. 2009, 28, 751-758. [CrossRef]

48. Herath, H.M.L.P.B.; Elvitigala, D.A.S.; Godahewa, G.I.; Whang, I.; Lee, J. Molecular insights into a molluscan transferrin homolog identified from disk abalone (Haliotis discus discus) evidencing its detectable role in host antibacterial defense. Dev. Comp. Immunol. 2015, 53, 222-233. [CrossRef]

49. Richards, R.C.; O'Neil, D.B.; Thibault, P.; Ewart, K.V. Histone H1: An Antimicrobial Protein of Atlantic Salmon (Salmo salar). Biochem. Biophys. Res. Commun. 2001, 284, 549-555. [CrossRef]

50. Fernandes, J.M.O.; Molle, G.; Kemp, G.D.; Smith, V.J. Isolation and characterisation of oncorhyncin II, a histone H1-derived antimicrobial peptide from skin secretions of rainbow trout, Oncorhynchus mykiss. Dev. Comp. Immunol. 2004, 28, 127-138. [CrossRef]

51. Cornet, V.; Henry, J.; Corre, E.; Le Corguillé, G.; Zatylny-Gaudin, C. The Toll/NF-kB pathway in cuttlefish symbiotic accessory nidamental gland. Dev. Comp. Immunol. 2015, 53, 42-46. [CrossRef] 
52. Li, Y.-F.; Liu, Y.-Z.; Chen, Y.-W.; Chen, K.; Batista, F.M.; Cardoso, J.C.R.; Chen, Y.-R.; Peng, L.-H.; Zhang, Y.; Zhu, Y.-T.; et al. Two toll-like receptors identified in the mantle of Mytilus coruscus are abundant in haemocytes. Fish Shellfish Immunol. 2019, 90, 134-140. [CrossRef]

53. Toubiana, M.; Gerdol, M.; Rosani, U.; Pallavicini, A.; Venier, P.; Roch, P. Toll-like receptors and MyD88 adaptors in Mytilus: Complete cds and gene expression levels. Dev. Comp. Immunol. 2013, 40, 158-166. [CrossRef]

54. Qiu, L.; Song, L.; Xu, W.; Ni, D.; Yu, Y. Molecular cloning and expression of a Toll receptor gene homologue from Zhikong Scallop, Chlamys farreri. Fish Shellfish Immunol. 2007, 22, 451-466. [CrossRef] [PubMed]

55. Wei, J.; Liu, B.; Fan, S.; Li, H.; Chen, M.; Zhang, B.; Su, J.; Meng, Z.; Yu, D. Differentially expressed immune-related genes in hemocytes of the pearl oyster Pinctada fucata against allograft identified by transcriptome analysis. Fish Shellfish Immunol. 2017, 62, 247-256. [CrossRef] [PubMed]

56. Toubiana, M.; Rosani, U.; Giambelluca, S.; Cammarata, M.; Gerdol, M.; Pallavicini, A.; Venier, P.; Roch, P. Toll signal transduction pathway in bivalves: Complete cds of intermediate elements and related gene transcription levels in hemocytes of immune stimulated Mytilus galloprovincialis. Dev. Comp. Immunol. 2014, 45, 300-312. [CrossRef] [PubMed]

57. Jiang, Q.; Liu, Z.; Zhou, Z.; Wang, L.; Wang, L.; Yue, F.; Wang, J.; Wang, H.; Song, L. Transcriptional activation and translocation of ancient NOS during immune response. FASEB J. 2016, 30, 3527-3540. [CrossRef]

58. Dziarski, R.; Gupta, D. The peptidoglycan recognition proteins (PGRPs). Genome Biol. 2006, 7, 232. [CrossRef]

59. Ni, D.; Song, L.; Wu, L.; Chang, Y.; Yu, Y.; Qiu, L.; Wang, L. Molecular cloning and mRNA expression of peptidoglycan recognition protein (PGRP) gene in bay scallop (Argopecten irradians, Lamarck 1819). Dev. Comp. Immunol. 2007, 31, 548-558. [CrossRef]

60. Su, J.; Ni, D.; Song, L.; Zhao, J.; Qiu, L. Molecular cloning and characterization of a short type peptidoglycan recognition protein (CfPGRP-S1) cDNA from Zhikong scallop Chlamys farreri. Fish Shellfish Immunol. 2007, 23, 646-656. [CrossRef]

61. Gonzalez, M.; Gueguen, Y.; Destoumieux-Garzon, D.; Romestand, B.; Fievet, J.; Pugniere, M.; Roquet, F.; Escoubas, J.-M.; Vandenbulcke, F.; Levy, O.; et al. Evidence of a bactericidal permeability increasing protein in an invertebrate, the Crassostrea gigas Cg-BPI. Proc. Natl. Acad. Sci. USA 2007, 104, 17759-17764. [CrossRef]

62. Gorbushin, A.M.; Borisova, E.A. Lectin-like molecules in transcriptome of Littorina littorea hemocytes. Dev. Comp. Immunol. 2015, 48, 210-220. [CrossRef]

63. Kumar, P.; Kannan, M.; ArunPrasanna, V.; Vaseeharan, B.; Vijayakumar, S. Proteomics analysis of crude squid ink isolated from Sepia esculenta for their antimicrobial, antibiofilm and cytotoxic properties. Microb. Pathog. 2018, 116, 345-350. [CrossRef]

64. Ezquerra-Brauer, J.M.; Miranda, J.M.; Chan-Higuera, J.E.; Barros-Velázquez, J.; Aubourg, S.P. New icing media for quality enhancement of chilled hake (Merluccius merluccius) using a jumbo squid (Dosidicus gigas) skin extract. J. Sci. Food Agric. 2017, 97, 3412-3419. [CrossRef] [PubMed]

65. Abdelmalek, B.E.; Sila, A.; Krichen, F.; Karoud, W.; Martinez-Alvarez, O.; Ellouz-Chaabouni, S.; Ayadi, M.A.; Bougatef, A. Sulfated polysaccharides from Loligo vulgaris skin: Potential biological activities and partial purification. Int. J. Biol. Macromol. 2015, 72, 1143-1151. [CrossRef] [PubMed]

66. Halverson, T.; Basir, Y.J.; Knoop, F.C.; Conlon, J.M. Purification and characterization of antimicrobial peptides from the skin of the North American green frog Rana clamitans. Peptides 2000, 21, 469-476. [CrossRef]

67. Conlon, J.M.; Coquet, L.; Leprince, J.; Jouenne, T.; Vaudry, H.; Kolodziejek, J.; Nowotny, N.; Bevier, C.R.; Moler, P.E. Peptidomic analysis of skin secretions from Rana heckscheri and Rana okaloosae provides insight into phylogenetic relationships among frogs of the Aquarana species group. Regul. Pept. 2007, 138, 87-93. [CrossRef]

68. Gao, B.; Zhu, S. Mesobuthus Venom-Derived Antimicrobial Peptides Possess Intrinsic Multifunctionality and Differential Potential as Drugs. Front. Microbiol. 2018, 9, 1-20. [CrossRef] [PubMed]

69. Oyama, L.B.; Girdwood, S.E.; Cookson, A.R.; Fernandez-Fuentes, N.; Privé, F.; Vallin, H.E.; Wilkinson, T.J.; Golyshin, P.N.; Golyshina, O.V.; Mikut, R.; et al. The rumen microbiome: An underexplored resource for novel antimicrobial discovery. npj Biofilms Microbiomes 2017, 3, 33. [CrossRef]

70. Azkargorta, M.; Bregón-Villahoz, M.; Escobes, I.; Ibáñez-Pérez, J.; Iloro, I.; Iglesias, M.; Diez-Zapirain, M.; Rabanal, A.; Prieto, B.; Moragues, M.-D.; et al. In-depth proteomics and natural peptidomics analyses reveal antibacterial peptides in human endometrial fluid. J. Proteom. 2020, 216, 103652. [CrossRef] 
71. Sangster, C.R.; Smolowitz, R.M. Description of Vibrio alginolyticus Infection in Cultured Sepia officinalis, Sepia apama, and Sepia pharaonis. Biol. Bull. 2003, 205, 233-234. [CrossRef]

72. Frans, I.; Michiels, C.W.; Bossier, P.; Willems, K.A.; Lievens, B.; Rediers, H. Vibrio anguillarum as a fish pathogen: Virulence factors, diagnosis and prevention. J. Fish Dis. 2011, 34, 643-661. [CrossRef]

73. Menanteau-Ledouble, S.; Kumar, G.; Saleh, M.; El-Matbouli, M. Aeromonas salmonicida: Updates on an old acquaintance. Dis. Aquat. Organ. 2016, 120, 49-68. [CrossRef]

74. Fichi, G.; Cardeti, G.; Perrucci, S.; Vanni, A.; Cersini, A.; Lenzi, C.; De Wolf, T.; Fronte, B.; Guarducci, M.; Susini, F. Skin lesion-associated pathogens from Octopus vulgaris: First detection of Photobacterium swingsii, Lactococcus garvieae and betanodavirus. Dis. Aquat. Organ. 2015, 115, 147-156. [CrossRef] [PubMed]

75. Martinez-Urtaza, J.; Lozano-Leon, A.; DePaola, A.; Ishibashi, M.; Shimada, K.; Nishibuchi, M.; Liebana, E. Characterization of Pathogenic Vibrio parahaemolyticus Isolates from Clinical Sources in Spain and Comparison with Asian and North American Pandemic Isolates. J. Clin. Microbiol. 2004, 42, 4672-4678. [CrossRef] [PubMed]

76. Mishra, B.; Wang, X.; Lushnikova, T.; Zhang, Y.; Golla, R.M.; Narayana, J.L.; Wang, C.; McGuire, T.R.; Wang, G. Antibacterial, antifungal, anticancer activities and structural bioinformatics analysis of six naturally occurring temporins. Peptides 2018, 106, 9-20. [CrossRef] [PubMed]

77. Cellura, C.; Toubiana, M.; Parrinello, N.; Roch, P. Specific expression of antimicrobial peptide and HSP70 genes in response to heat-shock and several bacterial challenges in mussels. Fish Shellfish Immunol. 2007, 22, 340-350. [CrossRef]

78. Bolger, A.M.; Lohse, M.; Usadel, B. Trimmomatic: A flexible trimmer for Illumina sequence data. Bioinformatics 2014, 30, 2114-2120. [CrossRef]

79. Grabherr, M.G.; Haas, B.J.; Yassour, M.; Levin, J.Z.; Thompson, D.A.; Amit, I.; Adiconis, X.; Fan, L.; Raychowdhury, R.; Zeng, Q.; et al. Full-length transcriptome assembly from RNA-Seq data without a reference genome. Nat. Biotechnol. 2011, 29, 644-652. [CrossRef]

80. Li, B.; Dewey, C.N. RSEM: Accurate transcript quantification from RNA-Seq data with or without a reference genome. BMC Bioinform. 2011, 12, 323. [CrossRef]

81. Haas, B.J.; Papanicolaou, A.; Yassour, M.; Grabherr, M.; Philip, D.; Bowden, J.; Couger, M.B.; Eccles, D.; Li, B.; Macmanes, M.D.; et al. De novo transcript sequence recostruction from RNA-Seq: Reference generation and analysis with Trinity platform for reference generation and analysis. Nat. Protoc. 2013, 8, 1494-1512. [CrossRef]

82. Buchfink, B.; Xie, C.; Huson, D.H. Fast and sensitive protein alignment using DIAMOND. Nat. Methods 2015, 12, 59-60. [CrossRef]

83. Petersen, T.N.; Brunak, S.; von Heijne, G.; Nielsen, H. SignalP 4.0: Discriminating signal peptides from transmembrane regions. Nat. Methods 2011, 8, 785-786. [CrossRef]

84. Krogh, A.; Larsson, B.; Von Heijne, G.; Sonnhammer, E.L.L. Predicting transmembrane protein topology with a hidden Markov model: Application to complete genomes. J. Mol. Biol. 2001, 305, 567-580. [CrossRef] [PubMed]

85. Finn, R.D.; Bateman, A.; Clements, J.; Coggill, P.; Eberhardt, R.Y.; Eddy, S.R.; Heger, A.; Hetherington, K.; Holm, L.; Mistry, J.; et al. Pfam: The protein families database. Nucleic Acids Res. 2014, 42, 222-230. [CrossRef] [PubMed]

86. Letunic, I.; Bork, P. 20 years of the SMART protein domain annotation resource. Nucleic Acids Res. 2018, 46, D493-D496. [CrossRef] [PubMed]

87. Hiller, K.; Grote, A.; Scheer, M.; Munch, R.; Jahn, D. PrediSi: Prediction of signal peptides and their cleavage positions. Nucleic Acids Res. 2004, 32, W375-W379. [CrossRef] [PubMed]

88. Waghu, F.H.; Barai, R.S.; Gurung, P.; Idicula-Thomas, S. CAMP R3: A database on sequences, structures and signatures of antimicrobial peptides: Table 1. Nucleic Acids Res. 2016, 44, D1094-D1097. [CrossRef] [PubMed]

89. Wang, G.; Li, X.; Wang, Z. APD3: The antimicrobial peptide database as a tool for research and education. Nucleic Acids Res. 2016, 44, D1087-D1093. [CrossRef]

90. Gautier, R.; Douguet, D.; Antonny, B.; Drin, G. HELIQUEST: A web server to screen sequences with specific -helical properties. Bioinformatics 2008, 24, 2101-2102. [CrossRef] 
91. Hetru, C.; Bulet, P. Strategies for the isolation and characterization of antimicrobial peptides of invertebrates. Methods Mol. Biol. 1997, 78, 35-49. [CrossRef]

92. Duval, E.; Zatylny, C.; Laurencin, M.; Baudy-Floc'h, M.; Henry, J. KKKKPLFGLFFGLF: A cationic peptide designed to exert antibacterial activity. Peptides 2009, 30, 1608-1612. [CrossRef]

(C) 2020 by the authors. Licensee MDPI, Basel, Switzerland. This article is an open access article distributed under the terms and conditions of the Creative Commons Attribution (CC BY) license (http://creativecommons.org/licenses/by/4.0/). 